\title{
Letter to the editor: left heart decompression in patients on venoarterial extracorporeal membrane oxygenation
}

\author{
Soo Jin $\mathrm{Na}^{1}$, Yang Hyun $\mathrm{Cho}^{2}$ \\ ${ }^{1}$ Department of Critical Care Medicine, Samsung Medical Center, Sungkyunkwan University School of Medicine, Seoul, Republic of Korea; \\ ${ }^{2}$ Department of Thoracic and Cardiovascular Surgery, Samsung Medical Center, Sungkyunkwan University School of Medicine, Seoul, Republic of \\ Korea \\ Correspondence to: Yang Hyun Cho, MD. Department of Thoracic and Cardiovascular Surgery, Samsung Medical Center, Sungkyunkwan University \\ School of Medicine, 81 Irwon-ro, Gangnam-gu, Seoul 06351, Republic of Korea. Email: mdcho95@gmail.com \\ Response to: van der Wal PS, van Steenwijk MPJ, Montenij LJ, et al. Prophylactic versus therapeutic left ventricular unloading during extracorporeal \\ membrane oxygenation, better safe than sorry? J Thorac Dis 2020;12:6412-5.
}

Submitted Sep 21, 2020. Accepted for publication Oct 10, 2020.

doi: 10.21037/jtd-20-2940

View this article at: http://dx.doi.org/10.21037/jtd-20-2940

We appreciate the valuable comments by van der Wal et al. (1). In our study, we showed the inferior outcome of the delayed or therapeutic left heart decompression (LHD) compared with prophylactic decompression (2). The pulmonary edema induced by venoarterial extracorporeal membrane oxygenation (VA ECMO) sustains a significant problem, even after proper LHD. Because the capillaries of lungs are exposed to rapidly rising pulmonary venous pressure, the plasma of the capillary blood initially leaks into the alveolar space and the flooded alveoli results in pulmonary edema. After various lengths of time, from several minutes to a few days, alveolar hypoxia can lead to destabilization of the intercellular junction, breakage of the barrier between capillaries and the alveoli, and impairment of alveolar fluid clearance (3). Additionally, it can cause bleeding into the airway, which is often misdiagnosed as coagulopathy-induced alveolar hemorrhage. The sequalae of severe left ventricular distension are bacteremia owing to destructed alveolar capillary membrane, hospitalacquired pneumonia, and acute respiratory distress. These complications become a significant contraindication for heart transplantation or left ventricular assist device. Therefore, the survival benefit of LHD suggested in recent studies is believed to be the result, in part, of prevention and treatment for serious problems associated with pulmonary edema $(4,5)$. We humbly agree that there is an important bias in our study. However, we are both researchers and active clinicians on the battlefield of intensive care. We advise not to lose the golden timing of LHD. The LHD procedure should be performed either prophylactically or at the early stage of left heart distension and pulmonary edema.

\section{Acknowledgments}

Funding: None.

\section{Footnote}

Provenance and Peer Review: This article was commissioned by the editorial office, Fournal of Thoracic Disease. The article did not undergo external peer review.

Conflicts of Interest: Both authors have completed the ICMJE uniform disclosure form (available at http://dx.doi. org/10.21037/jtd-20-2940). The authors have no conflicts of interest to declare.

Ethical Statement: The authors are accountable for all aspects of the work in ensuring that questions related to the accuracy or integrity of any part of the work are appropriately investigated and resolved.

Open Access Statement: This is an Open Access article distributed in accordance with the Creative Commons Attribution-NonCommercial-NoDerivs 4.0 International 
License (CC BY-NC-ND 4.0), which permits the noncommercial replication and distribution of the article with the strict proviso that no changes or edits are made and the original work is properly cited (including links to both the formal publication through the relevant DOI and the license). See: https://creativecommons.org/licenses/by-nc-nd/4.0/.

\section{References}

1. van der Wal PS, van Steenwijk MPJ, Montenij LJ, et al. Prophylactic versus therapeutic left ventricular unloading during extracorporeal membrane oxygenation, better safe than sorry? J Thorac Dis 2020;12:6412-5.

2. Na SJ, Yang JH, Yang JH, et al. Left heart decompression

Cite this article as: Na SJ, Cho YH. Letter to the editor: left heart decompression in patients on venoarterial extracorporeal membrane oxygenation. J Thorac Dis 2020;12(11):7081-7082. doi: $10.21037 /$ jtd-20-2940 at venoarterial extracorporeal membrane oxygenation initiation in cardiogenic shock: prophylactic versus therapeutic strategy. J Thorac Dis 2019;11:3746-56.

3. Roumy A, Liaudet L, Rusca M, et al. Pulmonary complications associated with veno-arterial extra-corporeal membrane oxygenation: a comprehensive review. Critical Care 2020;24:212.

4. Russo JJ, Aleksova N, Pitcher I, et al. Left Ventricular unloading during extracorporeal membrane oxygenation in patients with cardiogenic shock. J Am Coll Cardiol 2019;73:654-62.

5. Baldetti L, Gramegna M, Beneduce A, et al. Strategies of left ventricular unloading during VA-ECMO support: a network meta-analysis. Int J Cardiol 2020;312:16-21. 